\title{
SISTEM PENGARSIPAN DALAM PENERIMAAN BARANG PADA DIVISI MEAT HYPERMART LIPPO KARAWACI TANGERANG
}

\author{
Harjoyo \\ Dosen Prodi D-III Sekretari Universitas Pamulang \\ email :dosen00808@unpam.ac.id
}

\begin{abstract}
ABSTRAK
Penelitian ini membahas "Sistem Pengarsipan dalam Penerimaan Barang pada Divisi Meat Hypermart Lippo Karawaci, Tangerang”. Adapun tujuannya, untuk mengetahui sistem pengarsipan dan hambatan yang dialami dalam melaksanakan pengarsipan pada Divisi Meat Meat Hypermart. Suatu organisasi atau perusahaan juga selalu membutuhkan bantuan data dan informasi untuk menyelesaikan pekerjaan dan mengefektifkan manajemennya untuk dapat mencapai tujuan-tujuan dengan baik. Salah satu cara yang dilakukan oleh perusahaan tersebut dalam menghadapi perkembangan teknologi adalah dengan memiliki suatu sistem informasi yang cukup baik, cepat dan teliti. Nilai informasi ditentukan oleh lima karakteristiknya, yaitu ketelitian, ketepatan waktu, kelengkapan, keringkasan dan kesesuaian, karena dengan hal ini akan membantu kelancaran pekerjaan dalam kantor tersebut. Untuk mewujudkan hal tersebut arsip sangat berperan penting dalam sebuah kantor baik secara Konvesional (Manual) ataupun Digital.
\end{abstract}

Kata Kunci : Sistem Pengarsipan, Penerimaan Barang

\section{PENDAHULUAN}

\section{Latar Belakang Masalah}

Setiap organisasi atau perusahaan pasti memerlukan suatu unit yang mengelola segala sesuatu yang berhubungan dengan kegiatan administrasi, kegiatan administrasi pada suatu kantor pada dasarnya juga mempunyai suatu hasil seperti unit-unit lainnya. Hasil atau produk dari suatu kantor adalah surat, formulir dan laporan. Pengelolaan surat, formulir dan laporan yang dihasilkan dan diterima oleh suatu kantor pada akhirnya akan berhubungan dengan kearsipan.

Menurut kamus administrasi, kearsipan adalah suatu bentuk pekerjaan tata usaha yang berupa penyusunan dokumen-dokumen secara sistematis sehingga bilamana diperlukan lagi dokumen-dokumen itu dapat ditemukan secara cepat (Agus Sugiarto dan Teguh Wahyono, 2005:2). 
Suatu organisasi atau perusahaan juga selalu membutuhkan bantuan data dan informasi untuk menyelesaikan pekerjaan dan mengefektifkan manajemennya untuk dapat mencapai tujuan-tujuan dengan baik.

Salah satu cara yang dilakukan oleh perusahaan tersebut dalam menghadapi perkembangan teknologi adalah dengan memiliki suatu sistem informasi yang cukup baik, cepat dan teliti. Nilai informasi ditentukan oleh lima karakteristiknya, yaitu ketelitian, ketepatan waktu, kelengkapan, keringkasan dan kesesuaian, karena dengan hal ini akan membantu kelancaran pekerjaan dalam kantor tersebut. Untuk mewujudkan hal tersebut arsip sangat berperan penting dalam sebuah kantor baik secara Konvesional (Manual) ataupun Digital.

Dalam sebuah perusahaan, arsip diperlukan untuk memberi pelayanan kepada pihak lain dan untuk keperluan informasi intern dalam kantor tersebut. Oleh karena itu arsip sangat berpengaruh pada seluruh kegiatan yang berhubungan dengan pengelolaan disegala bidang yang terdapat dalam sebuah kantor. Arsip juga merupakan pusat ingatan dari sebuah kantor, dengan arsip dapat diketahui bermacam-macam informasi yang sudah dimiliki kantor tersebut sehingga dapat ditentukan sasaran yang akan dicapai dengan menggunakan potensi yang ada secara maksimal. Informasi yang diperoleh melalui arsip juga dapat menghindarkan salah komunikasi, mencegah adanya duplikasi pekerjaan dan membantu mencapai efisiensi pekerjaan.

Sistem pengelolaan dalam arsip meliputi berbagai kegiatan dalam mengklasifikasikan surat, memberi kode, menyimpan surat, memelihara secara tepat sampai mengenai cara penyingkiran dan pemusnahan surat yang sudah tidak dipergunakan lagi. Sistem sendiri adalah sekelompok komponen yang teratur yang saling berkaitan dengan rencana yang dibuatnya dalam rangka mencapai tujuan. Sedangkan pengelolaan adalah proses yang membantu merumuskan kebijakan dan tujuan organisasi / proses yang memberikan pengawasan pada suatu hal yang terlibat dalam pelaksanaan kebijakan dan pencapaian tujuan (Ibnu Syamsi, 1994:8).

Apabila arsip yang dimiliki oleh sebuah perusahaan kurang baik pengelolaannya,dapat mengakibatkan sulitnya menemukan informasi yang telah disimpan dan akhirnya dapat menghambat tahapan proses pekerjaan selanjutnya. Mengingat peran arsip sangat penting, maka sebaiknya arsip dikelola menggunakan sistem pengelolaan arsip yang baik dan benar.

Arsip merupakan kumpulan dokumen-dokumen berupa surat,rekaman,dan video yang dapat dijadikan sebagai bukti otentik dalam sebuah organisasi/sekolah untuk masa yang akan 
datang dan disimpan dengan menggunakan sistem tertentu agar dapat ditemukan secara cepat dan tepat.

Kearsipan merupakan suatu proses kegiatan penerimaan,pencatatan, penyimpanan dengan menggunakan sistem tertentu,pemeliharaan,penemuan kembali secara efektif dan efisien,penyusutan serta sampai pemusnahan surat/warkat.

Dalam Undang-undang Nomor 7 Tahun 1971 tentang ketentuan-ketentuan pokok kearsipan menyebutkan pengertian arsip:

1. Naskah-naskah yang dibuat dan diterima oleh Lembaga Negara dan Badan-Badan Pemerintahan dalam bentuk corak apapun, baik dalam keadaan tunggal maupun berkelompok, dalam rangka pelaksanaan kegiatan pemerintah.

2. Naskah-naskah yang disebut dan diterima oleh badan-badan swasta atau perorangan, dalam bentuk corak apapun baik dalam keadaan tunggal maupun berkelompok dalam rangka pelaksanaan kehidupan-kehidupan kebangsaan.

Dalam sebuah organisasi sangat penting yang namanya pengelolaan arsip karena jika tidak adanya pengelolaan kearsipan dengan baik maka akan mengganggu kelancaran kegiatan suatu organisasi/sekolah tersebut.

Adapun permasalahan yang banyak timbul di sebuah organisasi mengenai pengelolaan kearsipan adalah sebagai berikut:

1. Tidak dapat atau sulit menemukan kembali arsip dengan cepat dan tepat saat diperlukan.

2. Membiasakan menumpuk arsip pada sembarangan tempat, padahal arsip itu harus segera disimpan.

3. Kurang menyadari arti pentingnya suatu arsip bagi organisasi/sekolah.

4. Peminjaman oleh pihak lain tidak melalui prosedur yang benar atau terlalu lama.

5. Penyusunan arsip secara serampangan.

6. Petugas arsip kurang terampil.

Maka dari itu untuk mengatasi permasalahan-permasalahan yang terjadi dalam pengelolaan kearsipan harus ditinjau beberapa hal:

1. Penggunaan sistem kearsipan yang jelas dan tepat.

2. Fasilitas yang digunakan sesuai dengan standar operasional prosedur.

3. Petugas kearsipan harus memenuhi syarat.

4. Penyelenggaraan penyusutan arsip dengan benar.

5. Analisis kebutuhan kegiatan pengarsipan. 


\section{Identifikasi Masalah}

Berdasarkan Latar Belakang di atas, penulis mengidentifikasikan masalah, sebagai berikut:

1. Upaya yang dilakukan oleh Divisi Meat Hypermart Lippo Karawaci, Tangerang dalam penanganan arsip penerimaan barang.

2. Sistem yang dipergunakan dalam pengarsipan penerimaan barang.

3. Kendala dan hambatan yang dialami ketika melakukan pengarsipan penerimaan barang.

4. Kendala dan hambatan pengarsipan mempengaruhi kinerja Divisi Meat Hypermart Lippo Karawaci.

\section{Rumusan Masalah}

Berdasarkan uraian di atas pada latar belakang dan identifikasi masalah, untuk mencegah terjadinya ketimpangan dan kerancuan dalam pembahasan, maka diberikan suatu perumusan masalah. Adapun perumusan masalah yang dibahas dalam jurnal ini adalah sebagai berikut:

1. Sistem apa yang dipergunakan oleh Divisi Meat Hypermart Lippo Karawaci Tangerang dalam pengarsipan penerimaan barang?

2. Kendala dan hambatan apa saja yang dialami ketika melakukan pengarsipan pada Divisi Meat Lippo Karawaci Tangerang?

\section{LANDASAN TEORI}

\section{Kearsipan}

\section{Pengertian Arsip}

Di bawah ini dikemukakan berbagai pendapat pengertian Arsip adalah suatu kumpulan dokumen yang disimpan secara sistematis karena mempunyai suatu kegunaan agar setiap kali diperlukan dapat secara cepat ditemukan kembali.

Arsip (record) yang dalam Bahasa Indonesia disebut sebagai Dokumen pada pokoknya dapat diberikan pengetian sebagai setiap catatan tertulis baik dalam bentuk gambar ataupun bagan yang memuat keterangan-keterangan mengenai suatu subjek (pokok 
persoalan) ataupun peristiwa- peristiwa yang dibuat orang untuk membantu daya ingat orang (itu) pula.

Arsip adalah Kumpulan Dokumen yang disimpan secara teratur berencana karena mempunyai suatu kegunaan agar setiap kali diperlukan dapat cepat ditemukan kembali Menurut Agus Sugiarto (2005 : 5).

Arsip berasal dari bahasa asing, orang Yunani mengatakan "Archivum” yang artinya tempat untuk menyimpan, sering juga kata tersebut ditulis "Archeon" yang berarti balai kota (tempat untuk menyimpan dokumen) tentang masalah pemerintahan.

Sedangkan menurut Bashir Bartos (2013: 56). mengemukakan bahwa: Arsip adalah segala kertas, naskah, foto, film, microfilm, rekaman, suara, gambar peta, gambar bagan dan dokumen-dokumen lain dalam segala macam bentuk dan sifatnya, asli ataupum salinan serta dengan segala macam penciptaanya dan menghasilkan atau di terima oleh sesuatu organisasi atau badan, sebagai bukti dari tujuan organisasi, fungsi prosedur pekerjaan atau kegiatan pemerintah lainya atau karena pentingnya informasi yang terkandung di dalamnya.

\section{Pengertian Arsip menurut para ahli sebagai berikut:}

a. Pengertian arsip menurut Moekijat (2002: 75), File merupakan jenis arsip aktif (early archive). Arsip aktif mengandung pengertian arsip yang masih dipergunakan secara langsung dalam proses administrasi sehingga arsip ini masih terdapat di unit kerja setiap organisasi Pengertian arsip menurut Kamus Administrasi Perkantoran( adalah kumpulan warkat yang disimppan secara teratur berencana karena mempunyai suatu kegunaan agar setiap kali diperlukan dapat cepat ditemukan kembali.

b. Pengertian arsip menurut Undang-Undang No.43 Tahun 2009 adalah rekaman kegitan atau peristiwa dalam bentuk berbagai dan diterima oleh lembaga negara, pemerintah daerah, lembaga pendidikan, perusahaan, organisasi politik, organisasi kemasyarakatan, dan perseorangan dalam pelaksanaan kehidupan bermasyarakat, berbangsa dan bernegara

c. Pengertian arsip menurut Agus Sugiarto adalah kumpulan dokumen yang disimpan secara teratur berencana karena mempunyai suatu kegunaan agar setiap kali diperlukan dapat cepat ditemukan kembali.

d. Pengertian arsip menurut Hadi Abubakar adalah Arsip dalam bahasa Indonesia berasal dari bahasa Yunani yakni “arche" yang memiliki arti permulaan. Dalam beberapa waktu, arche berkembang menjadi "ta archia" Dalam hal ini ta archia memiliki arti sebagai 
catatan. Selanjutnya ta archia berubah lagi menjadi "archeon" yang berarti gedung pemerintahan.

Pengertian kearsipan menurut Ensiklopedia Administrasi(2010) adalah:

a. Penyimpanan warkat (filing) adalah suatu bentuk pekerjaan tata usaha yang berupa penyusunan warkat-warkat secara sistematis sehingga bila diperlukan lagi warkat-warkat itu dapat ditemukan kembali secara cepat.

b. Sistem penyimpanan warkat (filing system) adalah suatu rangkaian tata cara yang teratur menurut sesuatu pedoman untuk menyusun warkat-warkat sehingga bila diperlukan lagi warkat-warkat itu dapat ditemukan kembali secara cepat.

c. Pengertian arsip menurut Suraja (2006: 33) adalah naskah atau catatan yang dibuat dan diterima oleh organisasi pemerintah, swasta dan perorangan mengenai suatu peristiwa atau hak dalam kehidupannya, dan dalam corak apa pun, baik tunggal maupun berkelompok, yang memilki fungsi tertentu, dan disimpan secara sistematis, sehingga jika diperlukan dapat disediakan dengan mudah dan cepat. Arsip adalah suatu kumpulan warkat yang berguna dan disimpan dengan sistemasis sehingga saat diperllukan informasinya dapat ditemukan kembali dengan cepat dan tepat

\section{Pengertian Kearsipan}

Kearsipan merupakan suatu proses kegiatan penerimaan, pencatatan, penyimpanan dengan menggunakan sistem tertentu,pemeliharaan,penemuan kembali secara efektif dan efisien,penyusutan serta sampai pemusnahan surat/warkat. Kearsipan sebagai salah satu kegiatan dalam pembinaan manajemen perkantoran, merupakan hal yang sangat penting dan tidak mudah dalam pelaksanaannya. Keterampilan mengelola arsip harus dimiliki tenaga pengelola untuk membantu tugasnya, serta membantu kelancaran kerja secara keseluruhan bagi aparat instansi yang bersangkutan. Pengelolaan kearsipan yang baik dan benar akan membantu kelancaran tugas-tugas pekerjaan selanjutnya. Karena arsip merupakan salah satu sumber pengambilan keputusan pada setiap instansi. Buku Manajemen Kearsipan ini secara umum menyajikan tentang pengelolaan arsip kantor, baik arsip konvensional maupun arsip elektronik, dengan harapan dapat membantu para praktisi perkantoran apabila mengalami kesulitan dalam pengelolaan arsip. Buku tersebut juga dimaksudkan untuk dapat lebih memahami cara mengelola kearsipan dengan baik sesuai dengan standar pengelolaan yang 
diharapkan, sehingga bermanfaat bagi arsiparis, pengelola arsip, para mahasiswa kearsipan pada khususnya, dan para pembaca yang bergerak pada bidang administrasi perkantoran (Sularso Mulyono, Partono, 2011: 77). Menurut Arsip adalah Kumpulan Warkat yang disimpan secara teratur berencana karena mempunyai suatu kegunaan agar setiap kali diperlukan dapat cepat ditemukan kembali. Dengan keteraturan penyimpanan maka akan meningkatkan efisiensi dan efektivitas kegiatan dan produktivitas dapat dicapai.

Manajemen Kearsipan (2006:33) yaitu : Arsip adalah suatu kumpulan warkat yang memiliki guna tertentu, disimpan secara sistematis, dan dapat diketemukan kembali dengan cepat.

Pengertian Arsip dapat disimpulkan, bahwa Arsip adalah suatu kumpulan Dokumen penting yang disimpan secara teratur agar setiap kali diperlukan dapat ditemukan dengan cepat.

\section{Faktor Kearsipan yang baik}

Menurut Kamus Adminitrasi, kearsipan (filling) adalah suatu bentuk pekerjaan tata usaha yang berupa penyusunan dokumen- dokumen secara sistematis sehingga bila mana dipelukan lagi dokumen-dokumen dapat ditemukan kembali secara cepat.

\section{Adapun Faktor- faktor kearsipan yang baik adalah :}

a. Kepadatan, faktor kepadatan bermaksud tidak menggunakan terlalu banyak tempat, khususnya ruangan lantai.

b. Mudah dicapai, aspek kemudahan dicapai sangat diperlukan dalam kegiatan pengelolaan arsip.

c. Kesederhanaan, faktor kesederhanaan bermaksud agar sistem penggolongan atau sistem penataan arsip dapat dimengerti dan dilaksanakan oleh setiap petugas atau pegawai pada umunya.

d. Keamanan, bermaksud agar dokumen-dokumen harus diberikan tingkat keamanan yang tepat sesuai dengan kepentingannya.

e. Kehematan bermaksud bahwa sistem kearsipan harus hemat dalam biaya uang, tenaga kerja dan biaya lainya.

\section{Penataan Arsip dan Tujuannya}

Menurut Durotul Yatimah (2005 : 167), Penataan “Arsip (filling system) adalah proses mengklasifikasikan dan mengatur arsip dalam suatu tatanan yang sistematis dan 
logis, serta menyimpannya dalam suatu tempat yang aman agar arsip tersebut dapat secara cepat ditemukan saat dibutuhkan.

Tujuan Penaataan Arsip diantaranya:

a. Memberikan Pelayanan dalam menyimpan arsip.

b. Menemukan kembali arsip secara tepat, lengkap, akurat, relevan,dan tepat waktu, serta efesiensi.

c. Menunjang penyusunan arsip yang berdaya dan berhasil guna.

\section{Pengorganisasian Arsip}

Pengorganisasian Arsip merupakan bagian dari proses penyusutan arsip. Menurut Agus Sugiarto (2005 : 21 ) Di dalam pengorganisasian Arsip, yaitu membicarakan siapa yang melakukan pengelolaan arsip dalam suatu organisasi. Agar ada kejelasan dalam hal pembagian Tugas dan siapa yang menjadi tanggung jawabnya. Ada beberapa pengorganisasian arsip dalam kantor yang sudah dikenal yaitu:

a. Sentralisasi

Sentralisasi yaitu sistem pengelolaan arsip yang dilakukan secara terpusat dalam suatu organisasi, atau dengan kata lain penyimpanan arsip yang dipusatkan di satu unit kerja khusus yang lazim di sebut sentral lazim. Sistem ini lebih menguntugkan untuk di gunakan oleh organisasi atau perusahaan yang kecil.

b. Desentralisasi

Yaitu Pengelolaan Arsip yang dilakukan pada setiap unit kerja dalam suatu organisasi atau setiap unit mengelola arsipnya masing- masing. Sistem ini lebih menguntungkan untuk digunakan oleh organisasi atau perusahaan yang sudah besar.

c. Kombinasi sentralisasi dan Desentralisasi

Yaitu gabungan dari sistem sentralisasi dan desantralisasi untuk mengatasi kelemahan dari dua cara pengelolaan Arsip. Adapun kerugian pada sistem sentralisasi dan desantralisasi yaitu:

1) Kerugian sistem sentralisasi:

a) Tidak semua jenis arsip disimpan dengan satu sistem penyimpanan yang seragam.

b) Unit kerja yang memerlukan arsip akan memakan waktu lebih lama untuk memperoleh arsip yang diperlukan. 
c) Penyimpanan arsip tersebar di berbagai lokasi, dan dapat menimbulkan duplikasi arsip yang disimpan.

d) Kantor harus menyediakan peralatan dan perlengkapan arsip disetiap unit kerja.

e) Penataran dan latihan kearsipan perlu diadakan karena petugas- petugas umumnya bertugas rangkap dan tidak mempunyai latar belakang pendidikan kearsipan.

f) Pemusnahan arsip harus dilakukan setiap unit kerja dan ini merupakan pemborosan kegiatan.

\section{Fungsi arsip}

Arsip adalah kumpulan dokumen yang penting yang disimpan secara teratur atau berdasarkan sistem. Fugsi Arsip menurut Agus Sugiarto (2005 : 9) yaitu:

a. Arsip sebagai sumber ingatan atau memori. Arsip yang disimpan merupakan bank data yang dapat dijadikan rujukan pencarian informasi apabila diperlukan.

b. Arsip sebagai bahan pengambilan keputusan. Pihak menejeman dalam kegiatannya tentunya memerlukan berbagai data atau informasi yang akan digunakan sebagai bahan pertimbangan dalam pengambilan keputusan.

c. Arsip sebagai bukti atau legalitas. Arsip yang dimiliki organisasi memiliki fungsi sebagai pendukung legalitas atau bukti - bukti apabila diperlukan.

d. Arsip sebagai rujukan historis. Arsip yang merekam informasi masa lalu dan menyediakan informasi untuk masa akan datang.

\section{Syarat Arsip yang baik}

Arsip harus memiliki Syarat -syarat arsip yang baik menurut kamus adminitrasi perkantoran yaitu:

a. Dokumen harus masih mempunyai kegunaan.

b. Dokumen harus disimpan secara teratur dan berencana.

c. Dokumen harus dapat ditemukan dengan mudah dan cepat apabila ditemukan kembali.

\section{Jenis- Jenis Arsip}

Pengelolaan Arsip memegang peranan penting bagi jalannya suatu organisasi, yaitu sebagai sumber informasi dan sebagai pusat ingatan organisasi. Dalam pengelolaan arsip terbagi menjadi beberapa bagian, Menurut Agus Sugiarto (2005: 10) yaitu: 
a. Arsip menurut subjek atau isinya

Menurut subjek atau isinya, arsip dapat di bedakan menjadi beberapa macam, yaitu :

1) Arsip kepegawaian, contoh ; data riwayat hidup pegawai, surat lamaran, surat pengangkatan pegawai, rekaman presensi, dan sebagainya.

2) Arsip keuangan, contoh ; laporan keuangan, bukti pembayaran, daftar gaji, bukti pembelian, surat perintah membayar.

3) Arsip pemasaran, contoh; surat penawarn, surat pesanan, surat perjanjian penjualan, daftar pelanggan, daftar harga, dan sebagainya.

4) Arsip pendidikan, contoh ; kurikulum, satuan pelajaran, daftar hadir siswa, raport, transkrip mahasiswa, dan sebagainya.

b. Arsip menurut bentuk dan wujud fisik

Penggolongan ini lebih di dasarkan pada tampilan fisik media yang di gunakan dalam merekam informasi. Menurut bentuk dan wujud fisiknya arsip dapat di bedakan menjadi:

1) Surat, contoh ; naskah perjanjian atau kontrak, akte pendirian perusahaan, surat keputusan, notulen rapat, berita acara, laporan, tabel, dan sebagainya.

2) Pita rekaman

3) Microfilm

4) Disket

5) Compact disk ( CD )

c. Arsip menurut nilai atau kegunaanya

Penggolongan arsip ini lebih di dasarkan pada nilai dan kegunaanya. Dalam penggolongan ini ada bermacam-macam arsip, yaitu:

1) Arsip bernilai informasi, contoh; penggumuman, pemberitahuan, undangan, dan sebagainya.

2) Arsip bernilai adminitrasi, contoh ; ketentuan - ketentuan organisasi, surat keputusan, prosedur kerja, urain petugas pegawai, dan sebagainya.

3) Arsip bernilai hukum, contoh ; akta pendirian perusahaan, akta kelahiran, akta perkawinan, surat perjanjian, surat kuasa, keputusan peradilan, dan sebagainya.

4) Arsip bernilai sejarah, contoh ; laporan tahunan, notulen rapat, gambar atau foto peristiwa, dan sebagainya.

5) Arsip bernilai ilmiah, contoh ; hasil penelitian. 
6) Arsip bernilai keuangan, contoh ; kuitansi, bon penjualan, laporan keuangaan, dan sebagainya.

7) Arsip bernilai pendidikan, contoh ; karya ilmiah para ahli, kurikulum, satuan pelajaran, program pengajaran, dan sebagainya.

d. Arsip menurut sifat kepentingannya

Penggolongan ini lebih didasarkan pada sifat kepentingannya atau urgensinnya, dalam peggolongan ini ada beberapa macam arsip, yaitu :

1) Arsip tidak berguna (nonesensial ), contoh; surat undangan, memo, dan sebagainya.

2) Arsip berguna, contoh ; presensi pegawai, surat permohonan cuti, surat pesanan barang, dan sebagainya.

3) Arsip penting, contoh ; surat keputusan, daftar riwayat hidup pegawai, laporan keuangan, buku kas, daftar gaji, dan sebagainya.

4) Arsip vital, contoh; akte pendirian perusahaan, buku induk pegawai, sertifikat tanah atau bangunan, ijazah, dan sebagainya.

e. Arsip menurut fungsinya

Penggolongan ini lebih berdasarkan pada fungsi arsip dalam mendukung kegiatan organisasi. Dalam penggolongan ini ada dua jenis arsip, yaitu ;

1) Arsip dinamis yaitu arsip yang masih di pergunakan secara langsung dalam kegiatan perkantoran sehari - hari.

2) Arsip statis yaitu arsip yang sudah tidak di pergunakan secara langsung dalam kegiatan perkantoran sehari - hari.

f. Arsip menurut tempat atau pengelolaanya

Penggolongan ini berdasarkan pada tempat atau tingkat penggelolaanya, dan sekaligus siapa yang bertanggung jawab. Dalam penggolongan ini arsip dapat di bedakan menjadi ;

1) Arsip pusat, arsip yang di simpan secara sentralisasi atau berada di pusat organisasi. Berkaitan dengan lembaga pemerintah ; arnas pusat di Jakarta

2) Arsip unit, arsip yang berada di unit - unit dalam organisasi. Berkaitan dengan lembaga pemerintah ; arnas daerah di ibu kota provinsi.

g. Arsip menurut keasliannya

Penggolongan ini dasarkan pada tingkat keaslian suatu arsip atau dokumen. Dalam penggolongan ini arsip dapat dibedakan ;

1) Arsip asli, yaitu dokumen yang langsung terkena hentakan mesin ketik, cetakan Jurnal Sekretari | Vol. 6 No. 1 | Januari 2019 
printer, dengan tanda tangan dan legalisasi yang asli, yang merupakan dokumen utama.

2) Arsip tembusan, yaitu dokumen kedua, ketiga dan seterusnya, yang dalam proses pembuatannya bersama dengan dokumen adli, tetapi ditujukan pada pihak lain selain penerima dokumen asli.

3) Arsip salinan, yaitu dokumen yang proses pembuatannya tidak bersama dengan dokumen asli, tetapi memiliki kesesusain dengan dokumen asli.

4) Arsip petikan, yaitu dokumen yang berisi bagian dari suatu dokumen asli.

h. Arsip menurut kekuatan hukum

Penggolongan ini di dasarkan pada legalitas yang di lihat dari sisi hukum. Dari segi hukum arsip di bedakan menjadi dua macam, yaitu ;

1) Arsip otentik, adalah arsip yang di atasnya terdapat tanda tangan asli dengan tinta ( bukan fotocopy atau film ) sebagai tanda keabsahan dari isi arsip bersangkutan. Arsip otentik dapat di pergunakan sebagai bukti hukum yang sah.

2) Arsip tidak otentik adalah arsip yang di atasnya tidak terdapat tanda tangan asli dengan tinta. Arsip ini berupa fotocopy, film, microfilm, hasil print computer, dan lain sebagainya.

\section{Peralatan dan Perlengkapan Kearsipan}

Peralatan yang dipergunakan untuk menyimpan arsip dikelompokkan menjadi tiga :

a. Alat penyimpanan tegak

Yaitu jenis yang umum dipergunkan dalam kegiatan pengurusan arsip. Jenis ini disebut almari arsip (filling cabinet). Lemari standart dapat terdiri dari 2 laci, 3 laci, 4 laci, 5 laci, atau 6 laci. Ada dua macam lemari arsip yaitu:

1) Lemari arsip untuk diisi dengan folder biasa.

2) Lemari arsip untuk folder gantung yang mempunyai tempat untuk gantungan folder.

b. Alat penyimpanan menyamping

Yaitu tempat untuk menyimpan folder atau file dengan posisi menyamping sehingga alat ini tidak memerlukan tempat yang luas.peralatan ini disebut file lateral.

c. Alat penyimpanan berat 
Alat ini lebih banyak memakan biaya atas harganya yang kurang terjangkau. File ini terbagi menjadi tiga bagian yaitu:

1) File Kartu adalah file yang khusus dibuat untuk menyimpan kartu atau formulir dengan ukuran tertentu.

2) File structural adalah file untuk semua jenis dan ukuran formulir atau arsip.

3) File mobile (bergerak) adalah file yang dapat bergerak yang terletak di atas semacam rel yang memudahkan gerakan ke depan dan ke belakang.

Perlengkapan Penyimpanan (Filling Supplies) yang dipergunakan untuk menyimpan arsip yaitu :

a. Penyekat adalah lembaran yang dapat dibuat dari karton atau triplek yang digunakan sebagai pembatas dari arsip- arsip yang disimpan.

b. Map (Folder) adalah perlengkapan yang dipergunakan dengan berbagai bentuk dan model sesuai dengan kebutuhan untuk menaruh file (ukuran).

c. Penunjuk(Guide) adalah sebagai tanda untuk membimbing dan melihat cepat kepada tempat-tempat yang diinginkan di dalam file.

d. Kata tangkap adalah judul yang terdapat pada tonjolan file.

e. Perlengkapan Lain diantaranya adalah Label yaitu sejenis Stiker yang di pakai untuk membuat kode dan ditempelkan pada bagian- bagian tertentu.

\section{Sistem Penyimpanan Arsip}

a. Sistem penyimpanan arsip adalah sistem yang dipergunakan pada penyimpanan dokumen agar kemudahan kerja penyimpanan dapat diciptakan dan penemuan dokumen yang sudah disimpan dapat dilakukan dengan cepat bilamanan dokumen tersebut sewaktu-waktu dibutuhkan. Sistem penyimpanan menurut Agus Sugiato (2005:51) yaitu:

1) Sistem Abjad

Sistem abjad adalah sistem penyimpanan dokumen yang berdasarkan susunan abjad dari kata tangkap (nama) dokumen bersangkutan. dokumen disimpan berdasarkan urutan abjad, kata demi kata, huruf demi huruf. Nama dapat terdiri dari dua jenis, yaitu nama orang dan nama tunggal. sedangkan nama badan terdiri dari nama badan Pemerintah, Swasta dan Organisasi. 
2) Sistem Geografis

Sistem Geografis adalah sistem penyimpanan dokumen yang berdasarkan pada pengelompokkan menurut nama tempat. Sistem ini dikelompokan menjadi tiga yaitu:

a. Nama depan Negara

b. Wilayah Adminitrasi Negara

c. Wilayah Adminitrasi Khusus

3) Sistem Subjek

Sistem Subjek adalah sistem penyimpanan dokumen yang berdasarkan kepada isi dari dokumen bersangkutan. Daftar Klasifikasi Subjek dapat dibagi menjadi dua jenis yaitu:

a) Daftar klasifikasi Standar adalah daftar yang sudah merupakan standar umum di dunia Internasional.

b) Daftar Klasifikasi Buatan Sendiri adalah daftar klasifikasi yang dibuat sendiri oleh perusahaan karena berdasarkan atas dari fungsi, kebutuhan, dan tugas. Daftar klasifikasi buatan sendiri terdapat dua urutan yaitu urutan kamus dan urutan ensiklopedia.

4) Sistem Nomor

Sistem penyimpanan dokumen yang berdasarkan kode nomor sebagai pengganti dari nama orang atau nama badan. Penyimpanan Sistem nomor dikelompokan menjadi tiga yaitu:

a) Susunan Berurutan adalah Dokumen yang telah memperoleh nomor dari buku register/ buku nomor, maka disusun berdasarkan nomor dimulai dari nomor kecil sampai besar, sistem ini digunakan untuk jumlah korespoden yang kurang dari 5 digit.

b) Susunan Terminal digit adalah salah satu dari tiga cara menyusun dokumen pada tempat penyimpanan susunan digit. Nomor dari terminal digit terdiri dari 6 (enam) angka. Pada dua angka paling kanan sebagai penunjuk 1 (guide), nomor laci. dua angka di tengah sebagai penujuk 2, nomor label. Sedangkan dua angka paling kiri sebagai penunjuk 2 urutan kartu atau dokumen. 
c) Susunan Middle digit adalah salah satu dari tiga cara menyusun dokumen pada tempat penyimpanan susunan digit. Nomor dari terminal digit terdiri dari 6 (enam) angka. Pada dua angka paling kanan sebagai penunjuk 1 (guide), nomor urut. dua angka di tengah sebagai penujuk 2, nomor laci. Sedangkan dua angka paling kiri sebagai penunjuk 2 urutan label.

5) Sistem Kronologi

Sistem penyimpanan kronologi adalah merupakan sistem penyimpanan yang berdasarkan urutan waktu melingkup tanggal, bulan, tahun, dekade ataupun abad.

6) SistemWarna

Sistem Warna adalah penyimpanan dokumen yang penggunaannya berbentuk simbol atau tanda untuk mempermudah pengelompokan dan pencarian dokumen.

7) Penyusutan Arsip

Penyusutan Arsip adalah suatu kegiatan untuk mengurangi arsip dengan prosedur melalui pemindahan, penyerahan kepihak lain dan pemusnahan, dengan melihat kurun waktu tertentu. "Penyusutan Arsip merupakan kegiatan- kegiatan mengurangi jumlah arsip yang dikelola melalui kegiatan pemindahan, penyerahan kepihak lain dan pemusnahan." (Agus Sugiarto 2005 : 102). Kegiatan penyusutan dapat dilakukan dengan:

a) Pemindahan kategori Arsip aktif ke Arsip in aktif melalui penilaian terlebih dahulu.

b) Arsip yang masih aktif akan disimpan di filling cabinet sedangkan yang tidak akan diproses ke tahap selanjutnya.

c) Setelah pemindahan ke Arsip in aktif kemudian Arsip akan di proses terlebih dahulu ke micro film kemudian dimusnahkan, atau dapat segera langsung Dimusnakan, dan diserahkan ke ARNAS.

8) Penilaian Arsip

Penilaian terhadap Arsip di dasarkan pada nilai guna yang dimiliki oleh setiap jenis arsip. Kegiatan ini dilakukan sebelum terjadinya pemindahan atau pemusnahan arsip. Kirteria penilaian arsip yang umum digunakan oleh perusahaan adalah sistem ALFRED yaitu singkatan dari Administrative Value (Nilai Administrasi), Legal Value(Nilai Hukum), Financial Value(Nilai Uang), Research Value(Nilai 
Penelitian), Educational Value(Nilai Pendidikan), Documentary Value(Nilai Dokumentasi). Nilai ALFRED berkisar antara 0 sampai dengan 100, dihitung berdasarkan jumlah persentase dari keenam kompunennya. Berdasarkan nilai ALFRED terdapat 4 (empat) golongan arsip yaitu:

a) Arsip tidak berguna (persentase 0 - 9) arsip ini dapat dimusnahkan sesudah dipakai sementara. Paling lama arsip ini disimpan 3 (tiga) bulan di file aktif. contoh; surat undangan, memo, dan sebagainya.

b) Arsip beguna (persentase 10 - 49) Arsip ini berguna sementara dan dapat diganti dengan biaya rendah. Arsip disimpan di file aktif selama 2 (dua) tahun dan di file in aktif selama 10 (sepuluh) tahun, contoh: presensi pegawai, surat permohonan cuti, surat pesanan barang, dan sebagainya.

c) Arsip penting ( persentase 50 - 89 ) arsip ini melengkapi bisnis rutin dan dapat digantikan dengan biaya tinggi dan lama. Arsip disimpan di file aktif selama 5 (lima) tahun dan di file in aktif selama 25(dua puluh lima) tahun, contoh: surat keputusan, daftar riwayat hidup pegawai, laporan keuangan, buku kas, daftar gaji, dan sebagainya.

d) Arsip vital ( persentase 90 - 100 ) Arsip yang tidak boleh dimusnahkan atau dipindahkan dan sangat penting untuk kehidupan bisnis, contoh: akte pendirian perusahaan, buku induk pegawai, sertifikat tanah atau bangunan, ijazah, dan sebagainya.

9) Pemindahan Arsip

Pemindahan arsip adalah tindakan kegiatan memindahkan arsip- arsip dari arsip aktif (sering digunakan) ke pada arsip tak aktif (inaktif) karena tidak atau jarang sekali dipergunakan. Berdasarkan karakteristik arsip dan waktu pemindahan, secara umum dikenal dengan dua cara pemindahan arsip yaitu:

a) Perpindahan secara continu (prepectual)

Arsip dipindahkan ketika arsip tersebut selesai digunakan, dengan waktu pemindahan tidak tentu.

b) Pemindahan Secara Periodic

Arsip dipindahkan setelah satu periode ( umumnya 1 tahun). Ada dua cara pemindahan periodik yaitu: 
Pemindahan tunggal (satu periode) yaitu setelah 1 periode berlalu, arsip in aktif dipindahkan ketempat penyimpanan arsip lain, sehingga arsip yang ada pada filling cabinet hanya arsip aktif.

c) Pemindahan ganda (dua periode) yaitu setelah satu periode berlalu masih ada arsip-arsip inaktif tetapi lokasi penyimpanannya terpisah dengan arsip aktif.

10) Jadwal Retensi

Jadwal retensi adalah daftar yang berisi tentang jangka waktu penyimpanan arsip yang dipergunakan sebagai pedoman penyusutan arsip. Bentuk jadwal retensi berupa tabel dengan klasifikasi arsip. Jadwal retensi dapat berubah sesuai dengan kebutuhan perusahaan. Adapun contoh tabel jadwal retensi arsip menurut ALFRED sebagai berikut:

Tabel 1. Jadwal Retensi Arsip

Sumber (Teguh Wahyono 2005: 116)

\begin{tabular}{|c|l|c|c|c|}
\hline \multirow{2}{*}{ Golongan Arsip } & \multicolumn{1}{|c|}{ Arsip } & \multicolumn{2}{c|}{ Umur Arsip } & \multirow{2}{*}{$\begin{array}{c}\text { Abadi/ } \\
\text { Dimusnahkan }\end{array}$} \\
\cline { 3 - 5 } & & Aktif & in aktif & Abadi \\
\hline \multirow{2}{*}{ VITAL } & Akte Pendirian & - & - & Abadi \\
\cline { 2 - 5 } & Akte Tanah & - & - & Dimusnahkan \\
\hline \multirow{2}{*}{ PENTING } & Laporan Keuangan & 5 tahun & 25 tahun & Dimusnahkan \\
\cline { 2 - 5 } & Cek Bekas & 5 tahun & 25 tahun & Dimusnahkan \\
\hline \multirow{2}{*}{ BERGUNA } & Neraca & 2 tahun & 10 tahun & Dimusnahkan \\
\cline { 2 - 5 } & Laporan Tahunan & 2 tahun & 10 tahun & Dimusnahkan \\
\hline \multirow{2}{*}{ TIDAK BERGUNA } & Undangan & 1 bulan & - & Dimusnahkan \\
\cline { 2 - 5 } & Pengumuman & 1 bulan & - & \\
\hline
\end{tabular}

11) Penyerahan Arsip

Penyerahan Arsip merupakan tindakan eksternal, yaitu dari perusahaan kepada Arsip Nasional. Arsip tersebut berbentuk dokumen perusahaan yang memiliki nilai historis yang penggunaanya berkaitan dengan kegiatan pemerintah, kegiatan pembangunan nasional, kehidupan kebangsaan. Prosedur penyerahan arsip yaitu instansi yang bersangkutan meminta persetujuan terlebih dahulu dari kepala arsip nasional dengan jalan mengirimkan daftar arsipnya.

12) Pemindahan Arsip kedalam media Mikro Film 
Mikro Film adalah suatu proses fotografi dimana dokumen atau arsip direkam pada film dalam ukuran yang diperkecil untuk memudahkan Penyimpanan, Transportasi, dan Penggunaan mikro film dapat dibaca langsung melalui alat pembaca mikro film, dan bila mempunyai alat bantu cetak mikro film, maka arsip- arsip yang sama besar dengan orisinilnya dapat dicetak.

13) Pemusnahan Arsip

Pemusnahan arsip adalah kegiatan untuk menghancurkan secara fisik arsip yang sudah berakhir fungsinya serta tidak memiliki nilai guna. Pemusnahan arsip dapat dilakukan dengan cara:

a) Pembakaran yaitu dengan cara dibakar.

b) Pencacahan dengan cara menggunakan mesin atau alat pencacah baik manual maupun ataupun dengan mesin penghancur kertas.

c) Proses Kimiawi dengan cara menggunakan bahan kimia guna melunakan kertas dan melenyapkan tulisan.

d) Pembuburan dengan cara dicampur dengan air kemudian dicacah.

\section{Penerimaan Barang}

Pengertian Penerimaan Barang adalah "Menerima fisik barang dari pabrik, prinsipal atau distributor yang disesuaikan dengan dokumen pemesanan dan pengiriman dan dalam kondisi yang sesuai dengan persyaratan penanganan barangnya”

Di dalam aktifitas penerimaan barang ini terdapat 3 point penting yang tidak dapat dipisahkan satu dengan lainnya:

1. Fisik barang yang diterima

Adalah bentuk fisik barang yang harus dapat dirasa, diraba atau dilihat langsung. Penerimaan yang bukan berupa fisik barang dapat menyebabkan perbedaan proses dan hasil yang akan dicapai. Pada umumnya hasilnya adalah negatif. Jika ada penerimaan tanpa harus menangani fisik barangnya, maka perlu dilakukan proses tambahan untuk memastikan keabsahan proses tersebut.

a. Prinsip penerimaan barang adalah menerima FISIK BARANG secara langsung. Bukan hanya DOKUMENnya saja.

b. Secara fisik, barang dapat dilihat, diraba atau dirasa dan dapat dibandingkan dengan dokumen pengantaran. 
c. Pengecekan acak atau keseluruhan kondisi isi kemasan

d. Tanggal Kadaluarsa barang, nomor batch

e. Kuantitas barang VS dokumen

2. Dokumentasi

Dokumen pemesanan; barang diterima berdasarkan adanya dokumen yang mendasari berapa barang yang harus diterima, jenis barangnya apa dan untuk memastikan bahwa barang yang diterima adalah sama dengan barang yang dikirimkan.

a. Dokumen adalah pendamping barang yang secara fisik dapat dibaca dan dicocokan dengan barang yang dikirimkan.

b. Dokumen yang diperlukan minimal dokumen pengiriman (DN (Delivery Note), DO (Delivery Order), Packing List atau Surat Jalan).

c. Akan lebih baik jika dokumen Pemesanan (PO-Purchase Order) dilampirkan juga.

3. Cara Penanganan Barang

Persyaratan penanganan; kondisi khusus yang harus disiapkan pada saat barang tsb diterima. Apakah perlu ditangani pada suhu/temperatur khusus atau perlu dilakukan penanganan khusus dikarenakan faktor beratnya, tingkat kesulitannya atau masalah lainnya.

a. Tangani barang sesuai dengan siklus hidupnya

1) Suhu

2) Kadaluarsa

3) Maksimal tumpukan

b. Gunakan peralatan yang sesuai
1) Pallet
2) Drum
3) Forklit

c. Pahami aturan keselamatannya
1) Kimia
2) Racun
3) Meledak

Secara umum dapat dinyatakan bahwa penerimaan barang merupakan aktifitas operasional gudang yang sangat penting karena merupakan awal dari penanganan barang. Logika umum mengatakan bahwa penerimaan barang yang baik saja masih memungkinkan Jurnal Sekretari | Vol. 6 No. 1 | Januari 2019 
terjadinya kerusakan/kesalahan barang didalam gudang, terlebih jika pada saat penerimaan barang ditangani dengan cara yang tidak benar, dijamin kerusakan/kesalahan tsb pasti terjadi. Tahapan Penerimaan Barang:

1. Masuk gudang.

2. Parkir dan antri.

3. Bongkar muat di loading dock.

4. Penyusunan barang bongkaran.

5. Pengecekan barang vs dokumen.

6. Pemasukan data kedalam system (GRN).

7. Legitimasi dokumen.

8. Keluar gudang.

\section{HASIL DAN PEMBAHASAN}

\section{Gambaran Umum Perusahaan}

Matahari memulai kegiatan usahanya pada tahun 1958 dari sebuah toko di kawasan Pasar Baru Jakarta. Seiring perkembangan dan pertumbuhan ekonomi yang berdampak kepada perubahan gaya hidup dan kebutuhan masyarakat, tahun 1972 matahari menjadi pelopor konsep toserba di Indonesia dan menambah toko di luar pasar baru, dilanjutkan dengan membuka toko pertama di luar jakarta yaitu Sinar Matahari Bogor pada tahun 1980. Pada tahun 1992, Matahari resmi menjadi perusahaan terbuka dengan menawarkan sahamnya kepada masyarakat umum. Sejak saat itu PT MATAHARI PUTRA PRIMA Tbk. (MPPA) resmi menjadi perusahaan publik dan tercatat di Bursa Efek Indonesia. Saat ini MPPA memiliki gerai/cabang - cabang yang tersebar di wilayah republik Indonesia. Dan di tahun 2004 PT.MATAHARI PUTRA PRIMA Tbk. Membuat anak perusahaan bernama PT. HYPERMART dengan gerai yang pertama kali buka di mal WTC Serpong di tahun 2004, dan sekarang sudah membuka 94 gerai yang tersebar di seluruh Indonesia. Salah satunya di Lippo Supermal Karawaci yang sudah berdiri sejak 2006 hingga sekarang.

\section{Visi dan Misi}

Visi Hypermart adalah menjadi peritel multi format no. 1 di Indonesia. Sedangkan Misi Hypermart adalah Mentransformasi MPPA menjadi peritel multi format kelas dunia yang menghasilkan pertumbuhan organik penjualan dan laba yang berkelanjutan. 


\section{Logo Perusahaan}

\section{*

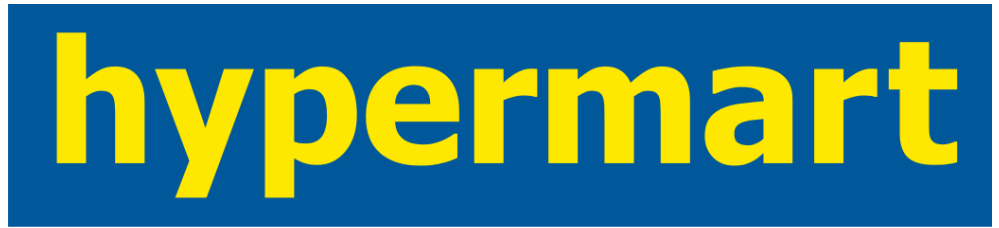 Low prices and more ...}

\section{Gambar Logo Hypermart}

\section{Hasil Penelitian}

\section{a. Tempat dan Waktu Praktik Kerja Lapangan}

Penulis melakukan penelitian di Hypermart cabang Lippo Karawaci dengan lokasi Supermall Karawaci di J1. Boulevard Diponegoro, Bencongan, Karawaci, Kota Tangerang, Banten 15810, pada divisi Meat, selama 3 (tiga ) bulan yaitu dari bulan September 2018 sampai dengan November 2018.

\section{Sistem yang dipergunakan oleh Divisi Meat Hypermart Lippo Karawaci Tangerang dalam pengarsipan penerimaan barang}

Seperti yang sudah dijelaskan sebelumnya terkait sistem pengarsipan, sebelum menjelaskan model atau sistem apa yang dipergunakan oleh divisi Meat dalam penerimaan barang, penulis akan menjelaskan terlebih dahulu pekerjaan/ kegiatan penerimaan barang pada divisi Meat.

Pengertian Penerimaan Barang adalah "Menerima fisik barang dari pabrik, prinsipal atau distributor yang disesuaikan dengan dokumen pemesanan dan pengiriman dan dalam kondisi yang sesuai dengan persyaratan penanganan barangnya"

Di dalam aktivitas penerimaan barang ini terdapat 3 point penting yang tidak dapat dipisahkan satu dengan lainnya:

1. Fisik barang yang diterima

Fisik barang yang diterima adalah bentuk fisik barang yang harus dapat dirasa, diraba atau dilihat langsung. Penerimaan yang bukan berupa fisik barang dapat Jurnal Sekretari | Vol. 6 No. 1 | Januari 2019 
menyebabkan perbedaan proses dan hasil yang akan dicapai. Pada umumnya hasilnya adalah negatif. Jika ada penerimaan tanpa harus menangani fisik barangnya, maka perlu dilakukan proses tambahan untuk memastikan keabsahan proses tsb. Prinsip penerimaan barang adalah menerima fisik barang secara langsung. Bukan hanya dokumennya saja.

a. Secara fisik, barang dapat dilihat, diraba atau dirasa dan dapat dibandingkan dengan dokumen pengantaran.

b. Pengecekan acak atau keseluruhan kondisi isi kemasan

c. Tanggal Kadaluarsa barang, nomor batch

d. Kuantitas barang vs dokumen

2. Dokumentasi

Dokumen pemesanan; barang diterima berdasarkan adanya dokumen yang mendasari berapa barang yang harus diterima, jenis barangnya apa dan untuk memastikan bahwa barang yang diterima adalah sama dengan barang yang dikirimkan.

a. Dokumen adalah pendamping barang yang secara fisik dapat dibaca dan dicocokan dengan barang yang dikirimkan.

b. Dokumen yang diperlukan minimal dokumen pengiriman DN (Delivery Note), DO (Delivery Order), Packing List atau Surat Jalan).

c. Akan lebih baik jika dokumen Pemesanan (PO-Purchase Order) dilampirkan juga.

3. Cara penanganan barang

Persyaratan penanganan; kondisi khusus yang harus disiapkan pada saat barang tsb diterima. Apakah perlu ditangani pada suhu/temperatur khusus atau perlu dilakukan penanganan khusus dikarenakan faktor beratnya, tingkat kesulitannya atau masalah lainnya.

Secara umum dapat dinyatakan bahwa penerimaan barang merupakan aktivitas operasional gudang yang sangat penting karena merupakan awal dari penanganan barang. Logika umum mengatakan bahwa penerimaan barang yang baik saja masih memungkinkan terjadinya kerusakan/kesalahan barang di dalam gudang, terlebih jika pada saat penerimaan 
barang ditangani dengan cara yang tidak benar, dijamin kerusakan/kesalahan tersebut pasti terjadi.

Tahapan Penerimaan Barang sesuai dengan asas First In First Out atau yang lazin disebut dengan FIFO System sebagai berikut:

a. Masuk gudang

b. Parkir dan antri

c. Bongkar muat di loading dock.

d. Pengecekan barang vs dokumen

e. Pemasukan data ke dalam sistem

f. Legitimasi dokumen

g. Keluar gudang

Penerimaan barang merupakan segala awal arus barang yang bergerak di gudang. Penerimaan barang dari pemasok atau rekanan memang kelihatan mudah, namun bila hal ini tidak memiliki sistem yang mengatur, maka bisa dipastikan akan mengganggu produktivitas. Hal-hal yang harus diperhatikan dalam penerimaan barang antara lain:

\section{Bukti Pemesanan (Purchase Order)}

Ketika satu pihak memesan sejumlah barang ke pemasok, maka dia akan mengirimkan PO ke pemasok. Barang sesuai jumlah PO ini nantinya akan dibawa ke Gudang tempat yang disiapkan oleh si pemesan. Tim Gudang tentunya tidak selalu tahu jenis barang apa yang dipesan, oleh sebab itu tim Gudang perlu memastikan kesesuaian PO dengan fisik barang yang ada. Setelah PO diperiksa dan sesuai dengan seluruh item yang dibawa, maka selanjutnya dibuat Bukti Tanda terima Barang.

5. Bukti Tanda Terima Barang

Bukti Tanda Terima Barang serta Faktur akan berhubungan dengan penagihan uang. Bukti Tanda Terima barang akan dijadikan dasar oleh pihak supplier untuk menagih ke pemesan barang. Pentingnya untuk membuat Bukti Tanda Terima Barang ini asli dan ada tanda-tanda yang dilampirkan, semisal PO atau surat lain yang menjamin keaslian dokumen ini. 
a. Operasional

Aktivitas operasional adalah bongkar barang, cek expired, cek kesesuaian pesanan serta memasukkan barang ke penyimpanan. Aktivitas operasional ini merupakan salah satu critical point karena:

1) Bongkar muat barang yang dilakukan oleh kuli bongkar rawan membuat rusak barang atau resiko kehilangan barang karena dicuri.

2) Cek kesesuaian barang dengan PO dan Expired Date barang dilakukan oleh staff penerimaan barang yang biasanya memiliki sejumlah alasan untuk tidak melakukan aktifitas ini dengan sejumlah alasan seperti : supaya cepat, sudah kenal dengan pemasok, disiplin melakukan sistem, dan lain-lain.

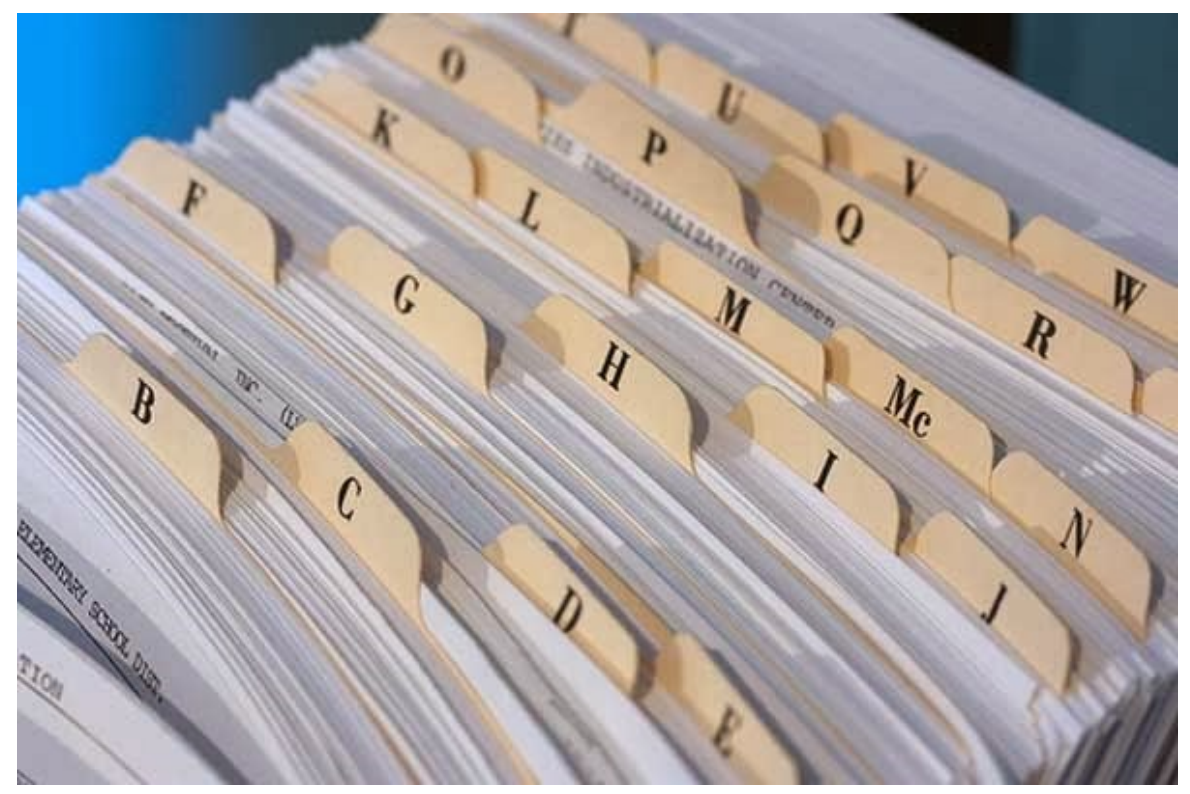

Gambar Guide Pada Sistem Abjad

Sumber: Data Sekunder

3) Penanganan pengarsipan penerimaan barang pada Divisi Meat Hypermart Lippo Mall Karawaci adalah dengan menggunakan sistem untuk menentukan sistem penyimpanan apa yang hendak digunakan hendaknya berdasarkan kebutuhan masing-masing perusahaan. pada dasarnya setiap manusia, organisasi, perusahaan (pemerintah/swasta) pasti memiliki nama. Atas dasar nama itulah sistem ini beranjak, perlu diketahui sistem ini adalah dasar dari sistem penyimpanan yang lain. Sistem Abjad adalah sistem yang tertua, langsung, dan 
paling banyak digunakan. Disebut sistem langsung (direct filing system) karena dapat langsung mencari arsip tanpa menggunakan kartu indeks.

Penanganan pengarsipan penerimaan barang pada Divisi Meat Hypermart Lippo Mall Karawaci adalah dengan menggunakan sistem Abjad. Sistem Abjad merupakan salah satu dari beberapa sistem penyimpanan arsip, selain sistem abjad, dikenal juga sistem subjek, sistem tanggal, sistem nomor, juga sistem wilayah. Setiap sistem ini pun memiliki keunggulan dan kelemahannya namun untuk menentukan sistem penyimpanan apa yang hendak digunakan hendaknya berdasarkan kebutuhan masing-masing perusahaan. pada dasarnya setiap manusia, organisasi, perusahaan (pemerintah/swasta) pasti memiliki nama. Atas dasar nama itulah sistem ini beranjak, perlu diketahui sistem ini adalah dasar dari sistem penyimpanan yang lain. Sistem Abjad adalah sistem yang tertua, langsung, dan paling banyak digunakan. Disebut sistem langsung (direct filing system) karena dapat langsung mencari arsip tanpa menggunakan kartu indeks.

Sistem ini juga sederhana dan mudah dipraktikkan karena pada umumnya orang mempunyai kecenderungan lebih mudah mengingat nama orang, badan/organisasi dibandingkan nomor dan angka.

Arsip-arsip dimasukan pada map berdasarkan nama perusahaan pemasok/supplier, misalnya:

a) Map " $\mathrm{ABC} "$

b) Map "INDOFOOD SUKSES MAKMUR"

c) Map "PEPSI COLA INDOBEVERAGES"

Dengan demikian ada tiga buah map bernama masing-masing ABS, INDOFOOD SUKSES MAKMUR, dan PEPSI COLA INDOBEVERAGES berisi arsip milik perusahaan tersebut.

Keuntungan/kelebihan pengarsipan menggunakan sistem abjad, antara lain:

1) Nama lebih mudah diingat oleh siapa pun

2) Petugas menginginkan agar dokumen disimpan dari nama yang sama 
3) Dokumen lebih sering dicari dan diminta melalui nama

4) Jumlah langganan yang berkomunikasi banyak

5) Dokumen yang berasal dari satu nama yang sama akan berkelompok menjadi satu

6) Surat masuk dan surat keluar disimpan bersebelahan dalam satu map

7) Mudah dikerjakan dan cepat ditemukan

8) Mudah diterapkan

Sedangkan kerugian/ kelamahan pengarsipan menggunakan sistem abjad adalah:

1) Pencarian dokumen untuk nama orang harus mengetahui nama belakangnya

2) Surat-surat yang walaupun berhubungan satu sama lain tetapi berbeda nama pengirimnya, akan terpisah dalam penyimpanannya.

3) Harus mempergunakan peraturan mengindeks sehingga memudahkan dalam pencarian kembali arsip ketika dibutuhkan.

4) Banyak orang yang memiliki nama sama, sehingga harus lebih teliti, karena kalau tidak teliti bisa salah dalam menempatkan dan menemukan kembali arsip.

Sistem abjad ini bergantung pada indeks arsip tersebut. Maka sebelum menggunakan harus memahami mengindeks arsip. Pada penyimpanan sistem abjad, pengelompokan arsip disusun berdasarkan nama orang/badan/organisasi. Sedang indeks adalah sarana penemuan kembali arsip dengan cara mengidentifikasikan naskah/berkas melalui penunjukan suatu tanda pengenal, yang dapat membedakan arsip tersebut dengan arsip lainnya. Secara singkat indeks dapat dikatakan sebagai tanda pengenal arsip. Dengan demikian, indeks dalam sistem abjad adalah indeks yang berdasarkan nama orang/nama badan. Dalam mengindeks nama orang/badan/organisasi, ada beberapa peraturan mengindeks yang sudah menjadi ketetapan yang berlaku secara universal dalam bidang kearsipan.

Kemudian langkah yang dilakukan selanjutnya adalah membuat daftar klasifikasi abjad yaitu pengelompokan arsip berdasarkan nama orang/badan/organisasi, secara sistematis dan logis, serta disusun berjenjang dengan tanda-tanda khusus yang berfungsi sebagai kode. 
Nama untuk menyimpan arsip terdiri dari beberapa macam, antara lain sebagai berikut:

a) Nama perorangan

b) Nama Perusahaan

c) Instansi Pemerintah

d) Nama Organisasi dan Perhimpunan

Setelah nama diindeks (apakah itu perorangan, perusahaan, pemerintah, organisasi), kemudian surat-surat diklasifikasikan berdasarkan abjad mulai dari A sampai Z, tetapi bila terdapat sejumlah nama yang sama maka penyusunnya dilakukan berdasarkan huruf kedua, ketiga, dan seterusnya.

Di balik setiap guide abjad inilah disimpan surat-surat yang sudah diklasifikasikan/dikelompokan berdasarkan susunan abjad.

Contoh:

1) Abdurahman

2) Ali Abdurahman

3) Waluyo Abdi

4) Haryanto Arbi

5) Abdullah Badawi

6) Gunawan Budianto

7) Raihan Binsar

8) Ratna Budianto

9) Chacha Cahyanti

10) Yulianti Cahyati

11) Septian Dwi Cahyo

12) Alia Mitha Cahaya

Setelah nama-nama tersebut diindeks dan diklasifikasikan, maka urutan surat-surat tersebut adalah sebagai berikut.

1) Abdi, Waluyo

2) Abdurahman

3) Abdurahman, Ali

4) Arbi, Haryanto 
5) Badawi, Abdullah

6) Binsar, Raihan

7) Budianti, Ratna

8) Budianto, Gunawan

9) Cahaya, Alia, Mitha

10) Cahyati, Chacha

11) Cahyati, Yulianti

12) Cahyo, Septian, Dwi

Kalau sudah diurutkan seperti di atas maka tinggal meletakkan surat tersebut kedalam guide yang sesuai dengan abjadnya, misal: Abdi, Waluyo disimpan pada guide A.

Adapun peralatan yang dipergunakan untuk mendukung pengarsipan sistem abjad antara lain:

1) Filling Cabinet

Laci filling cabinet dapat menampung sekitar 3500-4000 lembar. Jadi penggunaan filling cabinet dapat disesuaikan dengan banyaknya arsip yang ada di kantor. Laci tersebut dapat diberi kode A-Z. Akan tetapi, jika arsip dalam jumlah yang banyak, bisa saja satu laci hanya untuk 1 kode huruf. Jadi bias saja dibutuhkan 26 laci. Hal ini dilihat dari ruang lingkup dan besaran perusahaan atau banyaknya arsip yang akan disimpan.

2) Guide

Guide sebagai pembatas antara kelompok arsip yang satu dengan yang lainnya.

3) Hanging

Folder

Untuk menyimpan surat dalam filling cabinet, surat harus terlebih dahulu disimpan dalam hanging folder. Jumlahnya disesuaikan dengan kebutuhan. Hanging folder ditempatkan di belakang guide.

4) Alat Sortir

Alat sortir berguna untuk memudahkan dalam menyortir arsip. 


\section{Kendala dan hambatan apa saja yang dialami ketika melakukan pengarsipan pada Divisi Meat Lippo Karawaci Tangerang}

Semua kegiatan atau pekerjaan tentu akan ada suatu hambatan atau kendala dalam pelaksanaannya yang disebabkan beberapa faktor misalnya karena sumber daya manusia yang berhubungan dengan pendidikan, pengetahuan, dan perilaku. Faktor lingkungan dapat berupa fasilitas yang ada, tempat, dan mobilitas manusia itu sendiri.

Penulis menginventarisir hambatan atau kendala yang terjadi pada kegiatan pengarsipan di Divisi Meat Hypermart Lippo Karawaci Mall sebagai berikut:

1. Kurangnya lemari atau rak tempat penyimpanan

Jika ruang untuk menyimpan arsip kurang, otomatis lemari atau rak penyimpanannya juga kurang. Karena lemari atau rak terletak dalam satu ruangan khusus penyimpanan arsip. Kurangnya kemari ini juga membuat penyusunan arsip semakin susah untuk diketahui, karena memang letaknya juga tidak didalam lemari atau rak. Otomatis letaknya akan tidak sesuai pada prosedur penyimpanan. Dan juga akan mudah dipindahkan baik sengaja atau tidak sengaja oleh seseorang, tidak menuntuk kemungkinan ada orang iseng yang membuang arsip tersebut karena letaknya tidak pada tempat yang aman.

2. Tidak sistematis penyimpanannya

Masalah yang ini juga bisa terjadi karena faktor-faktor di atas, Karena ruangnya kurang dan kurang lemari juga akan menimbulkan masalah baru, misalnya tidak sistematis penyimpanannya. Hal ini dikarenakan sering berpindah tempat arsip yang tidak memiliki ruang dan lemari tersebut. Entah dipindahkan karena dibersihkan atau agar terhindar dari masalah lain. Arsip yang sering dipindahkan juga akan menyulitkan jika ingin mencari, juga tidak menuntut kemungkinan arsip atau dokumen tersebut hilang atau berada pada tempat yang tidak semestinya

3. Dokumen terlalu sering dibuka (Fast Moving File)

Kali ini merupakan kebalikan yang sebelumnya, yaitu dokumenn sering dibuka. Terlalu sering dibuka juga mengakibatkan kerusakan, karena jika dokumen terus dibuka akan melemah pada perekatnya, terlebih dokumen-dokumen lama yang belum begitu canggih alat yang dipakai untuk membuat. Sekiranya tidak mencakup hal yang penting sebaiknya jangan membuka arsip seenaknya, karena risikonya sobek atau lepas dari perekatnya.

4. Kedisiplinan petugas ketika membuka atau menyimpan arsip 
Hal ini diakibatkan oleh petugas lebih dari satu orang yang menangani arsip karena jam kerja terbagi dua shift yaitu pagi dan siang. Disamping masing-masing orang mempunyai latar belakang baik pendidikan, umur, sikap, dan pengetahuan yang berbeda, juga belum adanya system atau Standard Operating Procedure (SOP) penanganan arsip.

\section{PENUTUP}

\section{Kesimpulan}

Dari paparan yang sudah dijelaskan pada pembahasan di atas, penulis membuat kesimpulan-kesimpulan sebagai berikut:

1. Penanganan pengarsipan penerimaan barang pada Divisi Meat Hypermart Lippo Mall Karawaci adalah dengan menggunakan sistem Abjad. Alasan penggunaan sistem abjad adalah sistem ini sangat sederhana dan mudah dipraktikkan karena pada umumnya orang mempunyai kecenderungan lebih mudah mengingat nama orang, badan/organisasi dibandingkan nomor dan angka.

2. Hambatan atau kendala yang terjadi pada kegiatan pengarsipan di Divisi Meat Hypermart Lippo Karawaci Mall sebagai berikut:

a. Kurangnya lemari atau tempat penyimpanan

b. Tidak sistematis penyimpanannya

c. Dokumen terlalu sering dibuka (Fast Moving File)

d. Kedisiplinan petugas ketika membuka atau menyimpan arsip

\section{Saran}

1. Dari penanganan arsip yang dilakukan pada Divisi Meat Hypermart Lippo Karawaci dengan menggunakan sistem abjad walaupun dianggap sangat sederhana dan mudah dilakukan namun sebaiknya perlu dicoba menggunakan sistem lain seperti pengarsipan berdasarkan kronologi, karena erat kaitannya dengan tanggal pengiriman barang terutama makanan dan minuman yang bersifat cepat kadaluarsa sehingga akan mudah diketahui mana yang harus dikeluarkan dari gudang.

2. Hambatan atau kendala yang terjadi pada kegiatan pengarsipan di Divisi Meat Hypermart Lippo Karawaci Mall sebaiknya dilakukan pemecahannya antara lain: 
a. Kurangnya lemari atau tempat penyimpanan

Penulis menyarankan sebaiknya dibuat retensi file sehingga terkontrol dalam jumlah dan lamanya file disimpan sehingga hanya file-file yang masih aktif yang disimpan lemari.

b. Tidak sistematis penyimpanannya

Penulis menyarankan sebaiknya untuk menghindari kesalahan atau kehilangan atau tidak urutnya arsip maka diberi label atau nama dan pokok permasalahan arsip pada box penyimpanan tadi.

c. Dokumen terlalu sering dibuka (Fast Moving File)

Solusi untuk dokumen yang sering dibuka sangat berlawanan dengan yang jarang dibuka. Petugas harus membatasi siapa yang hendak mengambil atau membutuhkan, maksudnya jika sekiranya tidak terlalu penting tidak perlu membuka arsip atau dokumen tersebut. Hal ini ditujukan untuk menghindari kerusakan yang mungkin bisa terjadi karena arsip atau dokumen terlalu sering dibuka.

d. Kedisiplinan petugas ketika membuka atau menyimpan arsip Penulis menyarankan sebaiknya dibuat SOP (Standard Operating Procedure) penanganan arsip sehingga semua petugas mempunyai metode dan standar yang sama dalam bekerja.

\section{DAFTAR PUSTAKA}

Abubakar, Hadi (2006). Pola Kearsipan Modern Sistem Kartu Kendali. Jakarta: Djambatan

Basir Barthos. 2000. Manajemen Kearsipan. Jakarta: PT. Bumi Aksara.

Gie, Liang. 2000, Administrasi Perkantoran Modern, Yogyakarta : Liberty

Label. Ensiklopedia Administrasi. 10 Desember 2010 (19.55). ww.google.com.

Mulyono, Sularso. Dkk. 2005.Dasar-Dasar Kearsipan.Yogyakarta : Linerty

Mulyono, Sularso, Partono, Agung Kuswantoro. 2011. Manajemen Kearsipan. Semarang. Unnes Press.

2006. Manajemen Kearsipan. Yogyakarta: Bumi Aksara

Republik Indonesia. 2003. Undang-undang No. 7 Tahun 2003 tentang Ketentuan-Ketentuan Pokok Kearsipan.. Lembaran Negara RI Tahun 2003, No. 55. Sekretariat Negara. Jakarta. 
Sugiarto, Agus dan Teguh Wahyono.2005. Manajemen Kearsipan Modern dari Konvensional ke Basis Komputer. Yogyakarta: Gava Media.

Suraja Yohannes. 2006, Manajemen Kerasipan. Edisi Pertama, Malang:Penerbit Dioma 2008. Administrasi Perkantoran 2. Yogyakarta: Liberty 